\title{
Edukasi Persiapan Vaksinasi Covid-19 pada Guru dan Karyawan SD Kreatif Muhammadiyah Gombong
}

\author{
Education for Covid-19 Vaccination Preparation for Teachers and \\ Employees of Muhammadiyah Gombong Creative Elementary School
}

\author{
Hendri Tamara Yuda1, Putra Agina Widyaswara Suwaryo², Laeli Fitriyati², \\ Aseska Galah Mahardika ${ }^{4}$, Khusnul Dwi Haryani ${ }^{5}$ \\ 1,2,3,4,5 Universitas Muhammadiyah Gombong \\ *Corresponding author: hendritamara@gmail.com, hendritamara@unimugo.ac.id
}

Kata Kunci:
edukasi;
vaksinasi;
COVID-19

Keywords:

education;

vaccination;

Covid-19

\section{ABSTRAK}

Kegiatan ini dilakukan untuk meningkatkan pengetahuan guru dan karyawan tentang vaksinasi COVID-19. Edukasi dilakukan kepada 24 guru dan karyawan SD Kreatif Muhammadiyah Gombong. Media yang digunakan adalah Power point, video tentang vaksinasi. Evaluasi dilakukan melalui kuesioner pre dan posttest. Hasil menunjukan bahwa pengetahuan tentang COVID-19 setelah dilakukan edukasi adalah Baik sebanyak 24 peserta (100 $\%)$. Pengetahuan responden tentang Vaksinasi COVID-19 setelah dilakukan edukasi adalah baik sebanyak 24 peserta (100\%). Kecemasan responden tentang Vaksinasi COVID-19 setelah dilakukan edukasi adalah ringan sebanyak 11 peserta (45,83\%). Rasa takut terhadap program Vaksinasi COVID-19 setelah edukasi sebanyak 15 peserta (62,5\%) Edukasi menggunakan metode ceramah dan demonstrasi dengan video dapat meningkatkan pengetahuan guru dan karyawan tentang vaksinasi COVID-19.

ABSTRACT
The purpose of this activity is to increase the knowledge of teachers and
employees about the Covid-19 vaccination Education was carried out to 24
teachers and employees of Muhammadiyah Gombong Creative Elementary
School. The media used is Power point, video about vaccination. Evaluation is
done through pre and posttest questionnaires. The results show that
knowledge about Covid-19 after education is good as many as 24 participants
(100\%). Respondents' knowledge about Covid-19 vaccination after education
was good, as many as 24 participants (100\%). Respondents' anxiety about
Covid-19 vaccination after the education was carried out was mild as many as
11 participants (45.83\%). Fear of the Covid-19 Vaccination program after
education as many as 15 participants (62.5\%) Education using lecture and
demonstration methods with videos can increase teacher and employee
knowledge about Covid-19 vaccination.


PENDAHULUAN

Pandemi COVID-19 memberi tantangan besar dalam upaya peningkatan derajat kesehatan masyarakat Indonesia dan berdampak terhadap sistem kesehatan Indonesia yang terlihat dari penurunan kinerja pada beberapa program kesehatan. Hal ini disebabkan prioritasi pada penanggulangan pandemi COVID-19 serta adanya kekhawatiran masyarakat dan petugas terhadap penularan COVID-19. Di beberapa wilayah, situasi pandemi COVID-19 bahkan berdampak pada penutupan sementara dan/atau penundaan layanan kesehatan khususnya di posyandu dan puskesmas (Kemenkes, 2021).

Oleh karena itu, perlu segera dilakukan intervensi tidak hanya dari sisi penerapan protokol kesehatan namun juga diperlukan intervensi lain yang efektif untuk memutuskan mata rantai penularan penyakit, yaitu melalui upaya vaksinasi. Upaya telah dilakukan oleh berbagai negara, termasuk Indonesia, untuk mengembangkan vaksin yang ideal untuk pencegahan infeksi SARSCoV-2 dengan berbagai platform yaitu vaksin inaktivasi/inactivated virus vaccines, vaksin virus yang dilemahkan (live attenuated), vaksin vektor virus, vaksin asam nukleat, vaksin seperti virus (virus-like vaccine), dan vaksin subunit protein (Kemenkes, 2021).

Tujuan utama vaksinasi COVID19 adalah mengurangi transmisi/penularan COVID-19, menurunkan angka kesakitan dan kematian akibat COVID-19. Mencapai kekebalan kelompok di masyarakat (herd imunity) dan melindungi masyarakat dari COVID19 agar tetap produktif secara sosial dan

adal: penanganan pandemi COVID-19 yang menyeluruh dan terpadu meliputi aspek pencegahan dengan penerapan protokol kesehatan: menjaga jarak, mencuci tangan pakai sabun dan memakai masker (3M), vaksinasi COVID-19, dan 3T (Tes, Telusur, Tindak lanjut) (KPCPEN, 2021).

Vaksinasi

COVID-19

dilaksanakan dalam 4 tahapan mempertimbangkan ketersediaan, waktu kedatangan dan profil keamanan vaksin. Kelompok prioritas penerima vaksin adalah penduduk yang berdomisili di Indonesia yang berusia $\geq 18$ tahun. Salah satu penerima vaksin adalah guru di Indonesia. Guru bukan penerima vaksin prioritas pertama namun guru merupakan target primer sasaran kampanye komunikasi vaksinasi untuk menyampaikan pengetahuan tentang program vaksinasi tersebut. Namun banyak berita simpang siur dan hoax yang membuat masyarakat takut dan cemas terhadap program vaksinasi dari pemerintah.

\section{METODE}

Metode yang digunakan dalam kegiatan ini yaitu ceramah dan diskusi. Media yang digunakan adalah power point template dan video Langkah vaksinasi. Materi yang disampaikan saat pelatihan adalah kondisi COVID-19 terkini, vaksin COVID-19 dan Kejadian Ikutan Paska Imunisasi (KIPI).

Sasaran kegiatan ini adalah guru dan karyawan di SD Kreatif Muhamamdiyah Gombong. Pre test dilakukan dengan membagikan kuesioner pengetahuan tentang COVID-19 dan vaksinasi serta kecemasan dan ketakutan terhadap program vaksinasi COVID-19. telah edukasi dilakukan post test ıgan membagikan kuesioner yang 
sama.

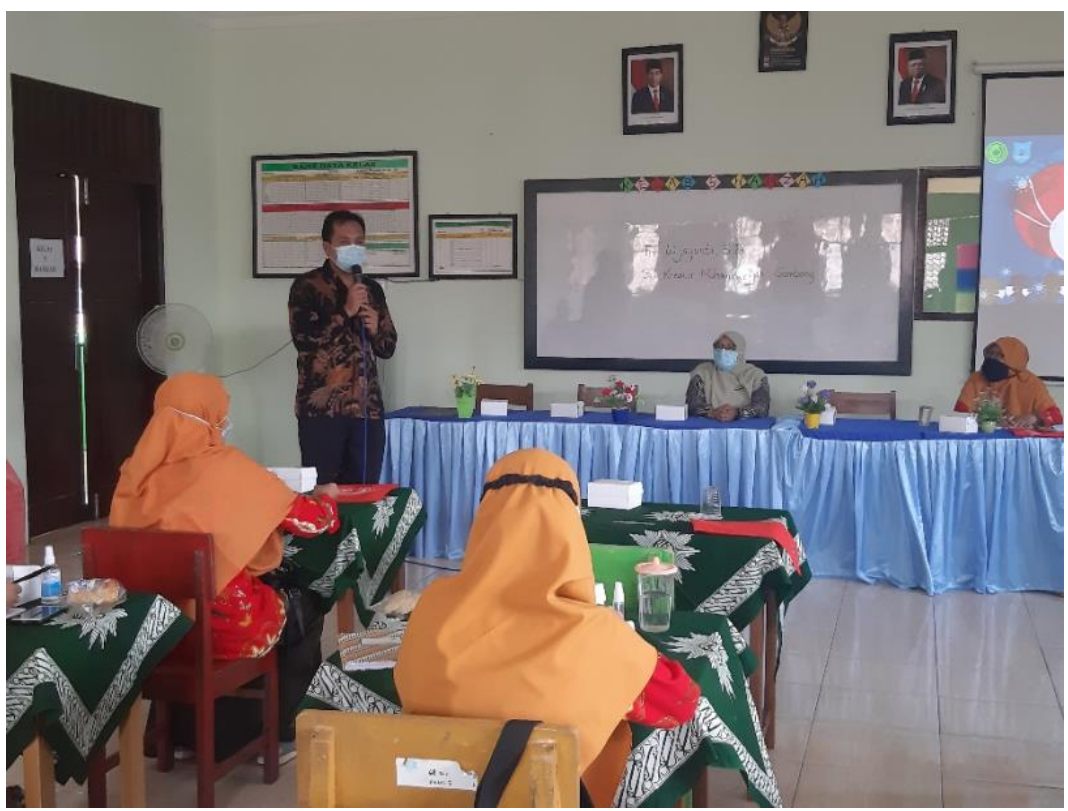

Gambar 1. Materi Update Kondisi Covid Terkini Oleh Hendri Tamara Yuda

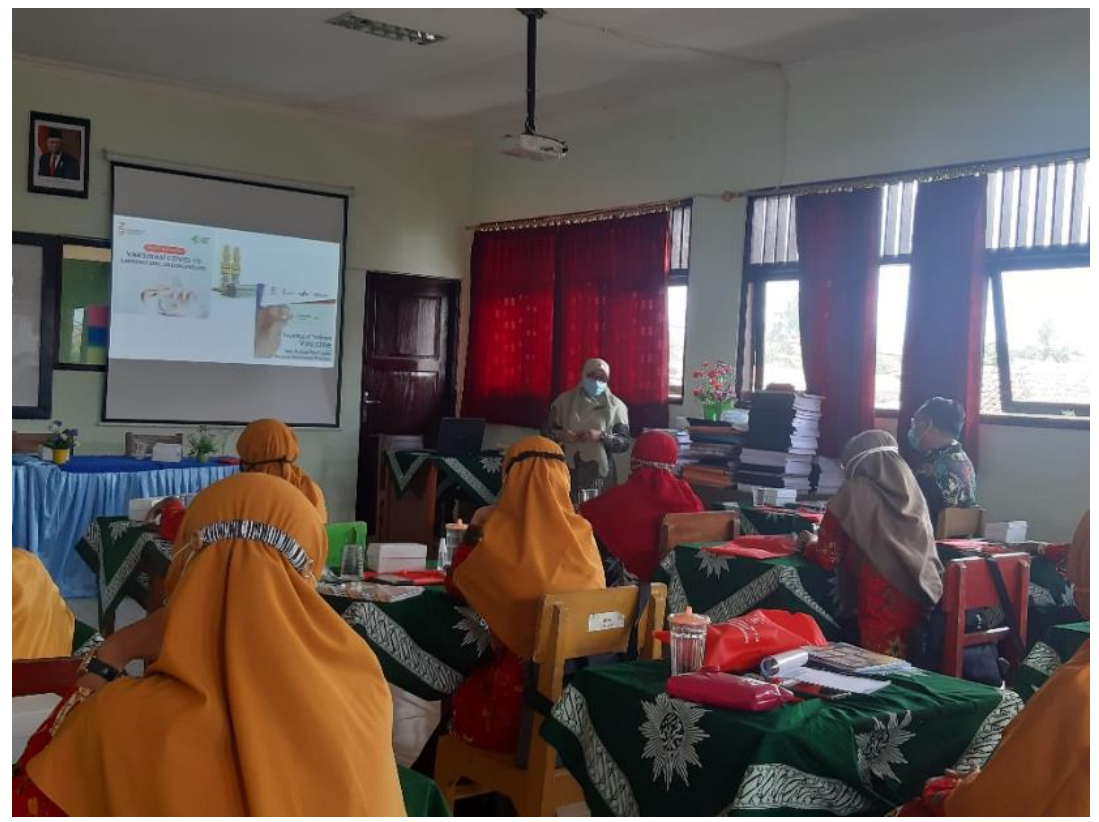

Gambar 2. Materi Vaksinasi Covid oleh Apt. Laeli Fitriyati, M.Farm 




Gambar 3. Edukasi persiapan vaksinasi

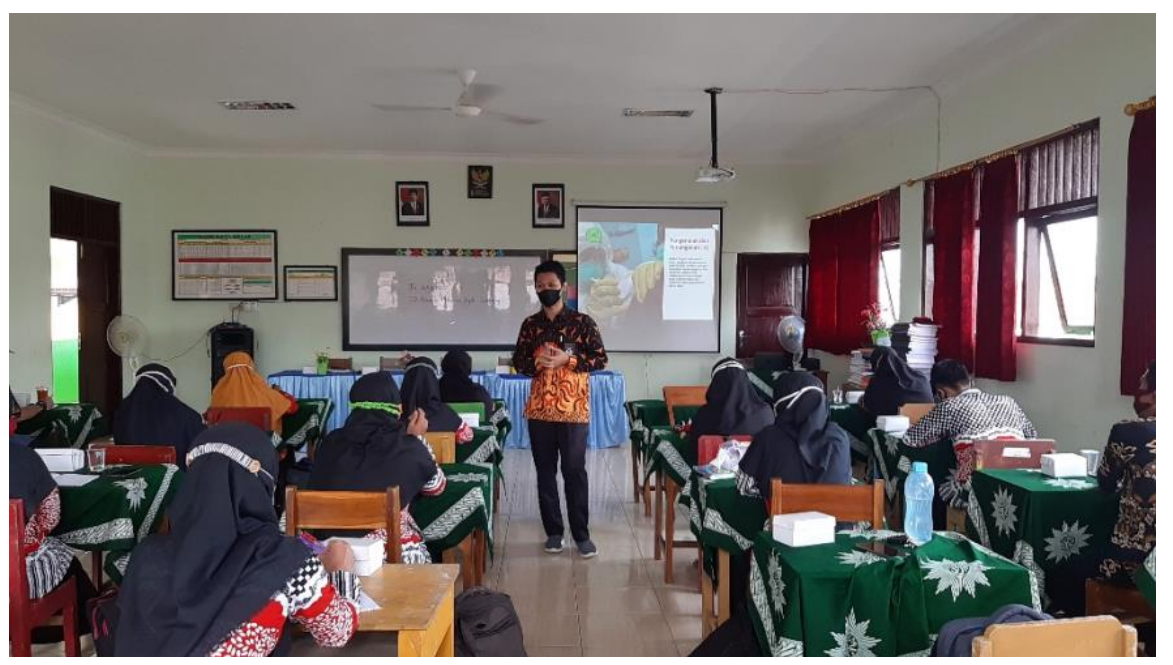

Gambar 4. Materi KIPI vaksinasi Covid-19 oleh Putra Agina W.S, M.Kep.

\section{HASIL DAN PEMBAHASAN}

\section{Karakteristik}

a. Karakteristik peserta

Karakteristik peserta edukasi persiapan vaksinasi COVID-19 pada guru dan karyawan SD Kreatif Muhammadiyah Gombong berdasarkan jenis kelamin berdasarkan Jenis Kelamin Sebagian besar adalah perempuan. Hal ini tergambar dalam tabel 1 distribusi frekuensi peserta berdasarkan jenis kelamin. 
Tabel 1. Distribusi Frekuensi Peserta Berdasarkan Jenis Kelamin $(n=24)$

\begin{tabular}{|c|c|c|}
\hline Jenis kelamin & Jumlah & \% \\
\hline Laki Laki & 7 & 29,17 \\
\hline Perempuan & 17 & 70,83 \\
\hline Jumlah & 24 & 100,0 \\
\hline
\end{tabular}

Sumber: Data Primer (2021)

b. Karakteristik peserta berdasarkan Pendidikan

Karakteristik

pendidikan peserta edukasi

persiapan vaksinasi

COVID-19 pada guru dan karyawan SD Kreatif Muhammadiyah Gombong mayoritas adalah Sarjana. Tabel peserta berdasarkan pendidikan disajikan pada Tabel 2 dibawah ini.

Tabel 2. Distribusi frekuensi peserta berdasarkan pendidikan $(n=24)$

\begin{tabular}{|c|c|c|}
\hline Pendidikan & Jumlah & \% \\
\hline Sarjana & 20 & 83,33 \\
\hline SMA & 4 & 16,67 \\
\hline Jumlah & 24 & 100,0 \\
\hline
\end{tabular}

Sumber: Data Primer (2021)

\section{Pengetahuan peserta tentang COVID-19}

a. Pengetahuan sebelum dilakukan edukasi

Pengetahuan responden tentang COVID-19 sebelum dilakukan edukasi

Sebagian besar baik. Tabel pengetahuan tentang covid sebelum dilakukan edukasi disajikan pada Tabel 3 dibawah ini.

Tabel 3. Pengetahuan tentang COVID-19 sebelum Dilakukan Edukasi ( $\mathrm{n}=24)$

\begin{tabular}{|c|c|c|}
\hline Pengetahuan & Jumlah & \% \\
\hline Baik & 22 & 91,67 \\
\hline Cukup & 2 & 8,33 \\
\hline Jumlah & 24 & 100,0 \\
\hline
\end{tabular}

Sumber: Data Primer (2021)

b. Pengetahuan setelah dilakukan edukasi

Pengetahuan responden tentang COVID-19 setelah dilakukan edukasi

mayoritas adalah Baik. Tabel pengetahuan tentang covid setelah dilakukan edukasi disajikan pada Tabel 4. dibawah ini.

Tabel 4. Pengetahuan tentang COVID-19 Setelah Dilakukan Edukasi (n=24)

\begin{tabular}{|c|c|c|}
\hline Pengetahuan & Jumlah & \% \\
\hline Baik & 24 & 100 \\
\hline Cukup & 0 & 0 \\
\hline Jumlah & 24 & 100,0 \\
\hline
\end{tabular}

Sumber: Data Primer (2021) 


\section{Pengetahuan peserta tentang Vaksinasi COVID-19}

Pengetahuan responden tentang vaksinasi COVID19 sebelum dilakukan edukasi mayoritas adalah Baik. Tabel pengetahuan a. Pengetahuan sebelum dilakukan edukasi tentang vaksinasi COVID19 sebelum dilakukan edukasi disajikan pada Tabel 5.

Tabel 5. Pengetahuan tentang Vaksinasi COVID-19 Sebelum Dilakukan Edukasi $(\mathrm{n}=24)$

\begin{tabular}{|c|c|c|}
\hline Pengetahuan & Jumlah & \% \\
\hline Baik & 21 & 87,5 \\
\hline Cukup & 3 & 12,5 \\
\hline Jumlah & 24 & 100,0 \\
\hline
\end{tabular}

Sumber: Data Primer (2021)

b. Pengetahuan setelah dilakukan edukasi

Pengetahuan responden tentang vaksinasi Covid-19 setelah dilakukan edukasi mayoritas adalah Baik. Tabel pengetahuan tentang vaksinasi Covid-19 setelah dilakukan edukasi disajikan pada Tabel 6.

Tabel 6. Pengetahuan tentang vaksinasi Covid-19 setelah dilakukan edukasi $(n=24)$

\begin{tabular}{|c|c|c|}
\hline Pengetahuan & Jumlah & \% \\
\hline Baik & 24 & 100 \\
\hline Cukup & 0 & 0 \\
\hline Jumlah & 24 & 100,0 \\
\hline
\end{tabular}

Sumber: Data Primer (2021)

\section{Kecemasan dalam program} vaksinasi Covid-19

Kecemasan responden tentang program vaksinasi Covid-19 sebelum dilakukan edukasi mayoritas adalah Berat. a. Kecemasan sebelum dilakukan edukasi

Tabel kecemasan tentang program vaksinasi Covid19 sebelum dilakukan edukasi disajikan pada Tabel 7.

Tabel 7. Kecemasan dalam Program Vaksinasi Covid-19 Sebelum Edukasi ( $\mathrm{n}=24)$

\begin{tabular}{|c|c|c|}
\hline Kecemasan & Jumlah & \% \\
\hline Ringan & 6 & 25 \\
\hline Sedang & 5 & 20,8 \\
\hline Berat & 13 & 54,2 \\
\hline Jumlah & 24 & 100,0 \\
\hline
\end{tabular}

Sumber: Data Primer (2021) 
b. Pengetahuan setelah

Kecemasan responden tentang program vaksinasi Covid-19 setelah dilakukan edukasi Sebagian besar adalah ringan. Tabel dilakukan edukasi

kecemasan tentang program vaksinasi Covid-19 setelah dilakukan edukasi disajikan pada Tabel 8.

Tabel 8. Kecemasan dalam Program Vaksinasi Covid-19 Setelah Edukasi (n=24)

\begin{tabular}{|c|c|c|}
\hline Kecemasan & Jumlah & \% \\
\hline Ringan & 11 & 45,83 \\
\hline Sedang & 8 & 33,33 \\
\hline Berat & 5 & 20,83 \\
\hline Jumlah & 24 & 100,0 \\
\hline
\end{tabular}

Sumber: Data Primer (2021)

5. Takut pada program vaksinasi Covid-19

Sebagian besar
responden takut dalam
program vaksinasi Covid-
19 sebelum dilakukan
edukasi. Tabel takut

a. Takut sebelum dilakukan edukasi

tentang program vaksinasi Covid-19 sebelum dilakukan edukasi disajikan pada Tabel 9.

Tabel 9. Takut dalam Program Vaksinasi Covid-19 Sebelum Edukasi $(n=24)$

\begin{tabular}{|c|c|c|}
\hline Takut & Jumlah & \% \\
\hline Ya & 15 & 62,5 \\
\hline Tidak & 9 & 37,5 \\
\hline Jumlah & 24 & 100,0 \\
\hline
\end{tabular}

Sumber: Data Primer (2021)

b. Takut setelah dilakukan edukasi

Kondisi takut

responden tentang program vaksinasi COVID-19

setelah dilakukan edukasi

Sebagian besar adalah tidak takut. Tabel takut tentang program vaksinasi COVID19 sebelum dilakukan edukasi disajikan pada tabel 10 .

Tabel 10. Takut dalam Program Vaksinasi Covid-19 Sebelum Edukasi $(n=24)$

\begin{tabular}{|c|c|c|}
\hline Takut & Jumlah & \% \\
\hline Ya & 9 & 37,5 \\
\hline Tidak & 15 & 62,5 \\
\hline Jumlah & 24 & 100,0 \\
\hline
\end{tabular}

Sumber: Data Primer (2021)

Berdasarkan tabel 3 mayoritas pengetahuan responden tentang COVID-19 sebelum dilakukan edukasi adalah baik sebanyak 22 responden $(91,67 \%)$ dan mayoritas pengetahuan responden tentang 
vaksinasi COVID-19 sebelum dilakukan edukasi adalah baik sebanyak 21 responden $(87,5 \%)$. Responden dalam kegiatan ini 83,33 $\%$ berlatar belakang pendidikan sarjana.

Menurut Notoatmodjo (2012), faktor-faktor yang mempengaruhi pengetahuan yaitu pendidikan, umur, pekerjaan dan faktor eksternal lainnya. Faktor yang bisa mempengaruhi pengetahuan diantaranya tingkat pendidikan dan belum pernah terpapar informasi. Informasi yang didapatkan lansia bisa berasal dari media cetak, media elektronik atau dari petugas kesehatan. Fasilitas-fasilitas sebagai sumber informasi yang dapat mempengaruhi pengetahuan seseorang, seseorang mempunyai fasilitas lengkap mempunyai pengetahuan lebih banyak pengetahuan dari pada orang yang mempunyai fasilitas sedikit karena fasilitas merupakan sumber informasi. Ketersediaan fasilitas juga ditunjang oleh penghasilan karena penghasilan merupakan sarana untuk mendapatkan fasilitas informasi. Informasi yang diperoleh dapat meningkatkan pengetahuan seseorang.

Menurut Notoatmodjo (2012) pendidikan seseorang mengenai kesehatan akan berpengaruh terhadap perilaku kesehatan, hal ini dikarenakan dengan pendidikan yang didapat akan memperoleh pengetahuan dan akan tercipta upaya pencegahan suatu penyakit. Semakin tinggi tingkat pendidikan seseorang akan memudahkannya menyerap ilmu pengetahuan, dengan demikian maka wawasannya akan lebih luas. Oleh karena itu, pengetahuan masyarakat tentang COVID-19 merupakan aspek yang sangat penting dalam masa pandemi seperti sekarang ini. Masyarakat perlu mengetahui penyebab COVID-19, karakteristik virusnya, tanda dan gejala, istilah yang terkait dengan COVID-19, pemeriksaan yang diperlukan dan proses transmisi serta upaya pencegahan penyakit tersebut (Purnamasari, 2020). Seseorang yang mempunyai pengetahuan yang baik terkait perilaku sehat maka ada kecenderungan untuk berperilaku yang baik pula (Gladys. 2016)

Berdasarkan tabel 7 mayoritas kecemasan responden tentang vaksinasi COVID-19 sebelum dilakukan edukasi adalah berat sebanyak 13 responden $(54,2 \%)$. Menurut Prawirohardjo cit Meitasari (2009), pendidikan merupakan salah satu faktor yang mempengaruhi kecemasan. Orang yang mempunyai pendidikan tinggi akan memberikan respon yang lebih rasional dibanding yang pendidikannya rendah atau yang tidak berpendidikan.

\section{SIMPULAN}

Kesimpulan pada kegiatan ini adalah mayoritas pengetahuan responden tentang COVID-19 sebelum dilakukan edukasi adalah baik sebanyak 22 responden $(91,67$ $\%$ ) dan mayoritas pengetahuan responden tentang vaksinasi COVID-19 sebelum dilakukan edukasi adalah baik sebanyak 21 responden $(87,5 \%)$. Mayoritas kecemasan responden tentang vaksinasi COVID-19 sebelum dilakukan edukasi adalah berat sebanyak 13 responden (54,2 \%), sedangkan mayoritas kecemasan responden tentang vaksinasi COVID-19 setelah dilakukan edukasi adalah ringan sebanyak 11 responden $(45,83 \%)$. Edukasi 
persiapan vaksinasi COVID-19 meningkatkan pengetahuan tentang COVID-19 dan vaksinasi COVID-19 serta dapat menurunkan kecemasan guru menghadapi vaksinasi.

\section{DAFTAR PUSTAKA}

Centers for Disease Control and Prevention. National Diabetes Statistics Report, 2020. Atlanta, GA: Centers for Disease Control and Prevention, US Department of Health and Human Services, 2020.

Gladys A. 2016. Hubungan Antara Usia, Jenis Kelamin, Lama Kerja, Pengetahuan, Sikap Dan Ketersediaan Alat Pelindung Diri (APD) Dengan Perilaku Penggunaan APD Pada Tenaga Kesehatan. Jurnal Publikasi Kesehatan Masyarakat Indonesia. Vol.3 (3).

Güner, R., Hasanoğlu, İ., \& Aktaş, F. (2020). Covid-19: Prevention and control measures in community. Turkish Journal of Medical Sciences, 50(SI1), 571-577 https://doi.org/10.3906/sag2004-146

Kemenkes. (2021). Juknis Pelaksanaan Vaksinasi dalam rangka penanggulangan Pandemi Covid-19

KPCPN. (20210). Paket Advokasi Vaksinasi Covid-19, Lindungi Diri Lindungi Negeri

Notoatmodjo, Soekidjo. 2012. Metodologi Penelitian Kesehatan. Jakarta: Rineka Cipta

Shereen, M. A., Khan, S., Kazmi, A., Bashir, N., \& Siddique, R. (2020). COVID-19 infection: Origin, transmission, and characteristics of human coronaviruses. Journal of Advanced Research, 24(1), 91-98.

https://doi.org/10.1016/j.jare.2 $\underline{020.03 .005}$ 